\title{
Different land-use intensities and their susceptibility to soil erosion
}

\author{
${ }^{1 *}$ Boglárka KeLler, ${ }^{2}$ Judit SzABÓ, ${ }^{3}$ Csaba CENTERI, ${ }^{2}$ Gergely JAKAB, \\ ${ }^{2}$ Zoltán SZALAI \\ ${ }^{1}$ NARIC Institute of Agricultural Engineering, Gödöllő \\ ${ }^{2}$ MTA Research Centre for Astronomy and Earth Sciences, Budapest \\ ${ }^{3}$ Institute of Nature Conservation and Landscape Management, Szent István University, \\ Gödöllö
}

\section{Introduction}

Soil water erosion is a worldwide environmental problem which can negatively affect soil fertility (MORGAN, 2009), reducing the amount of valuable soil organic matter and nutrient content (LAL, 2003), reducing soil water retention ability, etc. These all contribute to a decline in soil productivity (LAL, 1999), while the soil is a non-renewable resource (LAL, 1998). Soil degradation processes may generate many on-site and off-site environmental problems (VERSTRAETEN and POESEN, 2000; SHARPLEY et al., 1994).

Appropriate land use and land management have great importance for soil water erosion (FELIX-HEMINGSEN et al., 1997), greatly influencing soil quality. The most important factors in soil quality are the structural composition and fertility of the soil. These factors depend on the size and stability of soil aggregates, the organic carbon content of the soil and other agents. Conventional tillage itself greatly reduces the amount of soil organic carbon, increases soil compaction and destroys aggregates, so the use of conservation tillage methods is of increasing importance. On bare soil surfaces, the aggregates are broken down by raindrop impact during rainfall events and the smaller aggregates are washed away (RODRIGUEZ et al., 2002; SCHIETTECATTE et al., 2008). Soil erosion is a selective process, and soil organic matter (SZALAI et al., 2016) is usually the first to be removed by runoff, thus reducing soil resistance to degradation processes. Therefore, in erosion-prone areas, proper land use has a major role in managing soil functionality (RIMAL and LAL, 2009; JORDAN et al., 2005; PODMANICKY et al., 2011; ChEN et al., 2007; ErsKine et al., 2002; MOHAMMAD et al., 2010; PETŐ et al., 2008; VACCA et al., 2000; PENGA ÉS WANG 2012; KERTÉSZ et al., 2010; KOULOURI et al., 2007; SZILASSI et al., 2006).

In Europe soil water erosion processes on agricultural areas have been widely studied (HILl and SCHÜTt, 2000; DeVENTE and POESEN, 2005; BOARDMANN and PoEsen, 2006; CERDAN et al., 2010, etc.).

Climate change has raised the number, intensity and duration of rainfall events. According to the IPCC (2013) report, the frequency and intensity of extreme rainfall events are expected to increase in future decades. Climate change and the more intense, more erosive short duration rainfall events have a direct effect on soil

*Corresponding Author: BOGLÁRKA KELLER, NARIC Institute of Agricultural Engineering, Gödöllö, 4. Tessedik S., HU-2100

E-mail: keller.boglarka@mgi.naik.hu 
erosion (LI and FANG, 2016; JONES et al., 2014; ROUTSCLUK et al., 2014), as they increase the vulnerability of soils to erosion (NEARING et al., 2004). A large amount of precipitation over a short period may cause more runoff and soil loss, especially in summer heat waves. Heavy rainstorms rapidly reduce the infiltration capacity of the soil and increase soil sealing and crusting processes.

Rainfall simulation is a cost-effective, quick and well-known method to study and evaluate soil erosion processes. This method can be applied in situ under several land uses, such as arable land (CENTERI, 2006; FIENER et al., 2011; LE BISSONNAIS et al., 2005; LEYS et al., 2007; VOLF et al., 2007), grassland (JAKABSZALAI, 2005; KATO et al., 2009; KOLER et al., 2008), forest (SHERIDAN, 2008), vineyard (ARNAEZ et al 2007; COMINO et al., 2015) and under laboratory circumstances (ISERLOH et al., 2012; WON et al., 2012). In addition, rainfall simulators can be adjusted to different slope gradients and utilize variable rainfall intensities (SHEN et al., 2016; RIBOLZI et al., 2011)

In this study runoff and soil erosion data were collected for four high intensity rainfall simulation events on both arable land (AL) and grassland (GL). The main objectives were (1) to study the effects of different land use types on runoff and soil loss, (2) to compare the effects of different land uses on soil erosion.

\section{Materials and methods}

\section{Experimental area}

The study area can be found in Gerézdpuszta in Koppány Valley, situated in the north-eastern part of the South-Transdanubian Region of Hungary (Figure 1), $30 \mathrm{~km}$ to the south of Lake Balaton. It is a hilly landscape formed by loess deposited on a layer of Pannonian clay and sand sediments. The terraces of the stream are covered by hydromorphic soils, whereas the hill slopes are covered by Ramann-type brown forest soils and chernozems formed on loess, as published in the oldest soil maps.

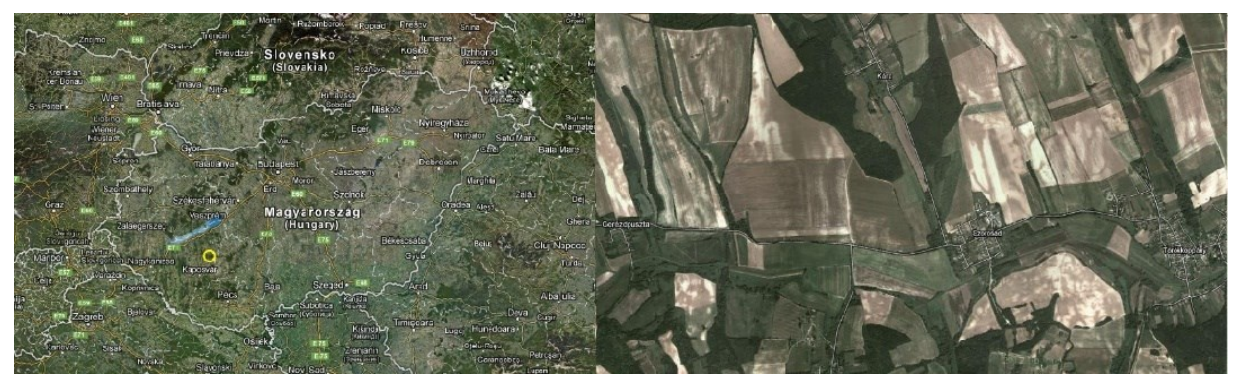

Figure 1

Location of Koppány Valley, Hungary 
On steep hillsides with intensive crop production, tillage may reach the parent material, so there is significant erosion on the hills (SZABÓ et al, 2015), as can be seen on Figure 1. Almost half of the agricultural areas are situated on slopes steeper than $12 \%$ and the famers use no soil protection methods. In addition the main crops on slopes covered with soils formed on loess are sunflower and maize.

\section{Soil parameters}

The soil texture on the studied arable and grassland areas was silty loam (Table 1), the main differences being in chemical properties, with higher $\mathrm{pH}$, $\mathrm{CaCO}_{3}$ and phosphorus content on the arable land, while the humus was near to the original state on the grassland.

Table 1

Physical and chemical soil properties

\begin{tabular}{l|ccccc}
\cline { 2 - 6 } & \multicolumn{5}{c}{ Physical soil properties } \\
\cline { 2 - 6 } & Clay $\%$ & Silt $\%$ & Fine sand \% & Coarse sand \% & Texture \\
\hline Arable land & 4.5 & 56.8 & 38.6 & 0.2 & Silty loam \\
Grassland & 3.1 & 57.3 & 39.1 & 0.5 & Chemical soil properties \\
\cline { 2 - 6 } & & & Humus $\%$ & AL-P $\left(\mathrm{mg} \mathrm{kg}^{-1}\right)$ & AL-K $\left(\mathrm{mg} \mathrm{kg}^{-1}\right)$ \\
\cline { 2 - 6 } & $\mathrm{pH}(\mathrm{KCl})$ & $\mathrm{CaCO}_{3} \%$ & 1 & 9.6 & 6.29 \\
\cline { 2 - 7 } Arable land & 7.6 & 13.3 & 3.5 & 3.72 & 9.84
\end{tabular}

\section{Rainfall simulation}

The study was carried out with a Shower Power-02 rainfall simulator, constructed at the Geographical Institute, Research Centre for Astronomy and Earth Sciences, Hungarian Academy of Sciences. Four rainfall events were simulated on both arable land (AL) and grassland (GL), involving $90 \mathrm{~mm} \mathrm{~h}^{-1}$ rainfall intensity on the arable land, and intensities of 90,110 and $130 \mathrm{~mm} \mathrm{~h}^{-1}$ on the grassland area. The intensities effectively reached were below those planned (Table 2).

The plots were on fenced ground with a plot size of $6 \mathrm{~m}^{2}(3 \times 2 \mathrm{~m})$. The device is equipped with two 80100 Veejet alternating nozzles. The rainfall intensity can be adjusted by changing the number of nozzle-swings during a given time. The runoff was collected by two metal triangles with a drain-pipe at the bottom of the plot. The runoff volume was registered through these triangles, and both the time and the amount of runoff were read when one of the two measuring barrels reached the 2-litre limit. 
Table 2

Rainfall intensities and slope sections during the rainfall events

\begin{tabular}{ccc} 
Planned intensity $\left(\mathrm{mm} \mathrm{h}^{-1}\right)$ & Measured intensity $\left(\mathrm{mm} \mathrm{h}^{-1}\right)$ & Slope (\%) \\
\hline & Grassland & 8.33 \\
130 & 96.73 & 8.33 \\
110 & 93.22 & 8.33 \\
90 & 96.48 & 8.33 \\
\hline & 78.4 & \\
90 & Arable land & 7.7 \\
90 & 80.44 & 8 \\
90 & 86.12 & 6.7 \\
90 & 84.68 & 8
\end{tabular}

\section{Results}

When rainfall simulation was performed under similar circumstances but different land use types no great differences in runoff were observed (Table 3). On average $4.32 \mathrm{~mm}$ and $5.53 \mathrm{~mm}$ runoff was measured for GL and AL, respectively. The GL results showed higher standard deviation and error (Figure 5). A lower amount $(\mathrm{ml})$ of runoff was recorded for GL than for $\mathrm{AL}\left(\mathrm{GL}_{\mathrm{avg}} 25922 \mathrm{ml}\right.$; $\left.\mathrm{AL}_{\text {avg }} 33207 \mathrm{ml}\right)$.

Table 3

Summary of results obtained for different land uses

\begin{tabular}{c|lcccccc} 
Land use & $\begin{array}{c}\text { Basic } \\
\text { statistic }\end{array}$ & $\begin{array}{c}\text { Runoff } \\
(\mathrm{mm})\end{array}$ & $\begin{array}{c}\text { Runoff } \\
(\mathrm{ml})\end{array}$ & $\begin{array}{c}\text { Runoff } \\
\text { coefficient }\end{array}$ & $\begin{array}{c}\text { Infiltration } \\
(\mathrm{mm})\end{array}$ & $\begin{array}{c}\text { Soil } \\
\text { loss } \\
\left(\mathrm{t} \mathrm{ha}^{-1}\right)\end{array}$ & $\begin{array}{c}\text { Suspended } \\
\text { sediment } \\
\text { load }\left(\mathrm{g} \mathrm{l}^{-1}\right)\end{array}$ \\
\hline \multirow{3}{*}{ Grassland } & AVG & 4.32 & 25921.75 & 0.33 & 10.47 & 0.04 & 1.09 \\
& $\mathrm{SD}$ & 2.15 & 12870.55 & 0.20 & 5.70 & 0.01 & 0.62 \\
& $\mathrm{SE}$ & 1.07 & 6435.28 & 0.10 & 2.85 & 0.01 & 0.31 \\
\hline \multirow{2}{*}{$\begin{array}{c}\text { Arable } \\
\text { land }\end{array}$} & AVG & 5.53 & 33207.50 & 0.48 & 6.20 & 0.58 & 10.61 \\
& $\mathrm{SD}$ & 0.65 & 3909.89 & 0.08 & 1.78 & 0.14 & 1.60 \\
& $\mathrm{SE}$ & 0.33 & 1954.94 & 0.04 & 0.89 & 0.07 & 0.80
\end{tabular}

The runoff coefficient characterizes the relationship between rainfall and runoff during a rainfall event. The higher this value, the greater is the flow rate and the lower the infiltration rate. On average, higher values were obtained for AL than 
for GL ( $\mathrm{GL}_{\text {avg }} 33 \%$; $\mathrm{AL}_{\text {avg }} 48 \%$ ). The measurements revealed a high correlation between rainfall intensity and runoff for $\mathrm{AL}\left(\mathrm{r}^{2}=0.9108\right)$ and a moderate correlation for GL $\left(\mathrm{r}^{2}=0.5457\right)$, where the rainfall intensity negatively affected the runoff rate and increased the infiltration $\left(\mathrm{r}^{2}=0.4919\right)$ (Figures 2-3).

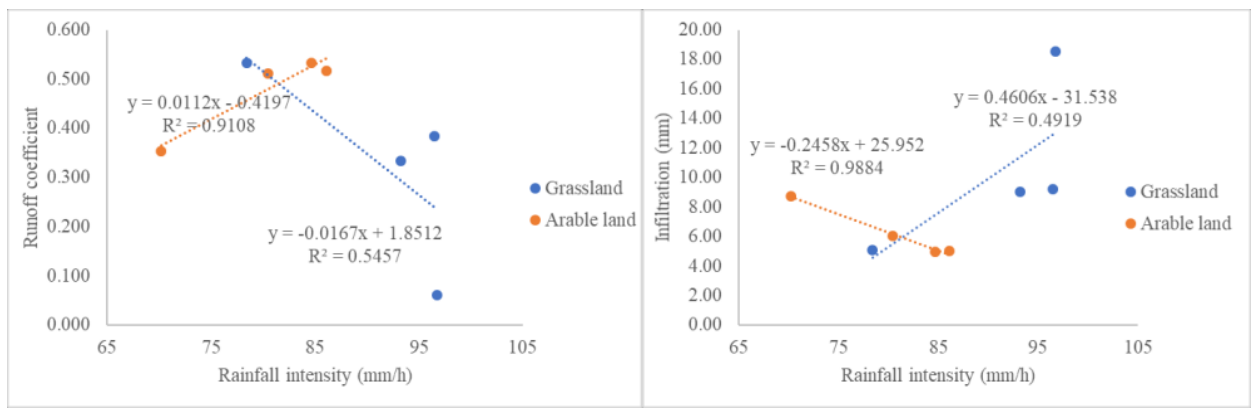

Figures 2-3

Effect of rainfall intensity on runoff coefficient and infiltration

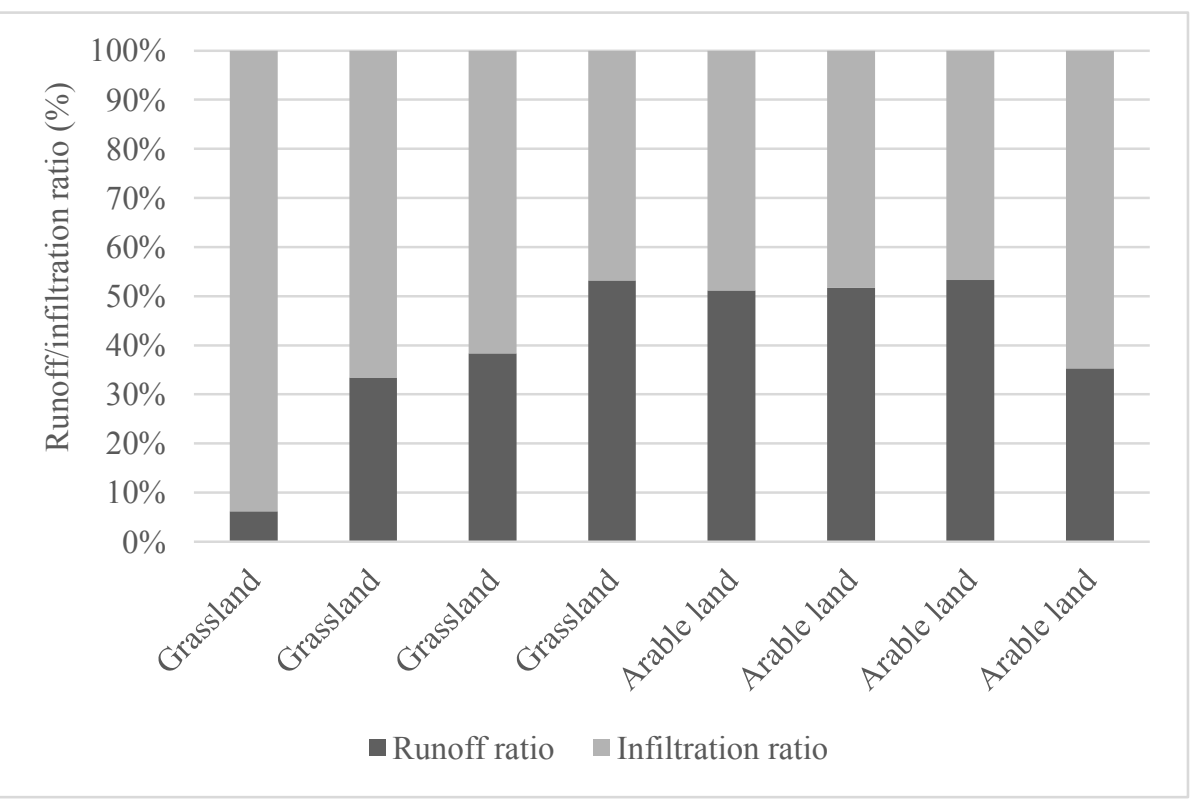

Figure 4

Runoff-infiltration ratios for different rainfall simulations

Besides the runoff coefficient, the runoff-infiltration ratio was also evaluated (Figure 4). Generally, a higher infiltration ratio was measured for GL, while for AL 
the runoff rate exceeded the infiltration rate in most cases, resulting in higher soil loss and suspended sediment load (Figure 6)

The most striking results were found for the suspended sediment load (Figures 5-6), where there was an almost 10-fold difference between GL and AL.

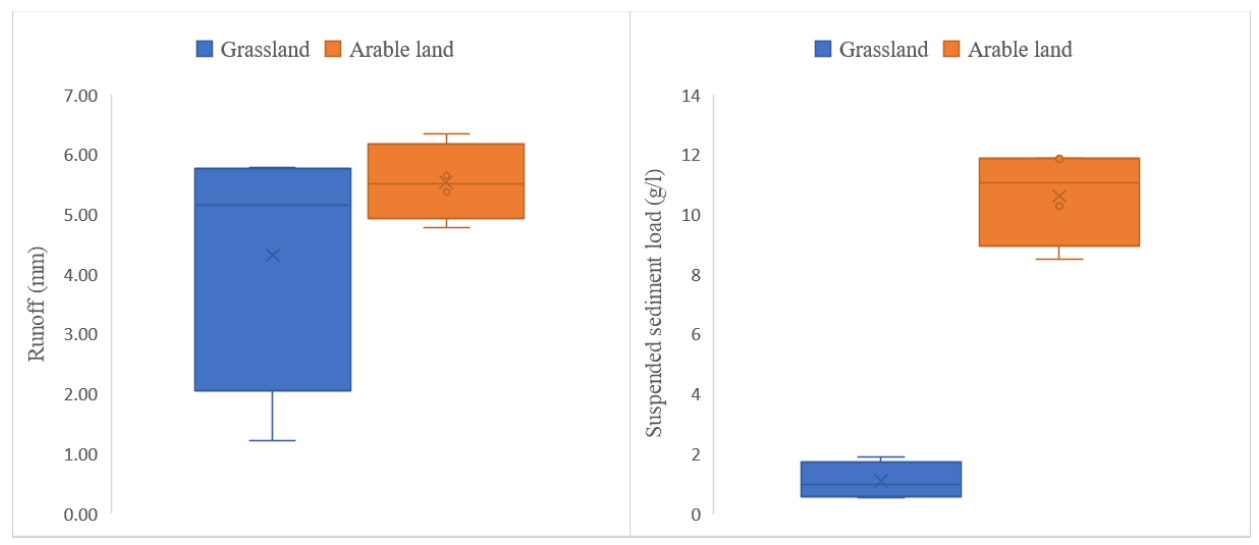

Figures 5-6

Runoff and suspended sediment load results between two land use intensities

\section{Conclusions}

It can be concluded from the results that the runoff and soil loss rate were higher on arable land (even at slightly lower rainfall intensities), leading to more concentrated suspended sediment loads. Similar rainfall intensities resulted in almost tenfold differences in suspended sediment load on AL, with greatly reduced infiltration.

In most cases infiltration was exceeded by runoff on AL. The results confirmed expectations that grassland would generate less runoff thanks to the better porosity, thick surface cover and greater surface roughness.

On AL rainfall intensity and runoff coefficient were in positive correlation, while in the case of GL increasing rainfall intensity decreased the runoff rate and moderately increased infiltration. Similar observations were made by NASSIF and WILSON (1975), BOWYER-BOWER (1993), JAKAB and SZALAI (2005) and SZABÓ et al. (2017), who found that soil permeability increases proportionally with higher rainfall intensity, partly due to the increasing pressure of the water. Based on the suspended sediment load the two land use intensities were unambiguously distinguishable.

It is obvious that while the runoff values of GL overlapped those of AL to some extent, the suspended sediment load differed greatly, with no overlap between the values of the two land use intensities. The suspended sediment load values clearly formed two distinctive groups. This is in agreement with the findings of Rimal and LAL (2009), JORDAN et al. (2005), PODMANICKY et al. (2011), 
Chen et al. (2007), Erskine et al. (2002), Mohammad et al. (2010), Petö et al. (2008), VACCA et al. (2000), PENGA and WANG (2012), KerTÉSZ et al. (2010), KoULOURI et al. (2007) and SZILASSI et al. (2006),who stated that proper land use has a major role in managing soil functionality. As arable farming is of increasing importance for the expanding world population, it would be important to find a balance by producing crops that provide enough soil cover to reduce the suspended sediment load to a sustainable limit. Our prime interest is for less soil to be lost than is formed under the given circumstances.

The present results suggest that there must be other important factors, besides chemical soil properties, such as biological soil activity and the water stored in plants, which are rarely considered in field experiments. Earthworms and other soildwelling animals, the plant leaf area, and plant remnants (both roots and the holes they leave after decay) have a tremendous effect on the infiltration rate and permeability, thus greatly influencing both runoff and, more importantly, the suspended sediment load.

The results emphasise the importance of adequate land use, which has a major role in climate resilience, SOC conservation and retention, and a reduction in soil loss.

\section{Summary}

Adaptation is the most important strategy to reduce the effect of climate change and soil erosion. During this process adequate, rational land use is necessary to ensure climate resilience. Therefore, the main objective in this study was to evaluate the susceptibility of different land use intensities (arable land and grassland) to soil erosion. The rainfall simulation method is a good tool to measure and estimate soil erosion in situ. The comparative measurements were carried out in the field with a Shower Power-02 simulator on $6 \mathrm{~m}^{2}$ plots in Gerézdpuszta, where the slope angles were $\sim 8 \%$ and the simulated rainfall events had high intensities $\left(\sim 70-96 \mathrm{~mm} \mathrm{~h}^{-1}\right)$. The runoff and soil loss were significantly higher from arable land. The runoff-infiltration ratio and runoff coefficient showed lower infiltration capacity in the case of arable land. On average, the suspended sediment loads were tenfold higher under intensive land use. In the case of grassland a moderate increase in infiltration was observed due to higher rainfall intensity, as also reported in the literature. The rainfall simulation method provides good data for soil loss estimations.

Keywords: soil erosion, different land uses, soil loss, runoff

\section{References}

Arnaez, J., Lasanta, T., Ruiz-Flaño, P., Ortigosa, L. (2007): Factors affecting runoff and erosion under simulated rainfall in Mediterranean vineyards. Soil \& Tillage Research. 93. 324-334.

BoArdmann, J., Poesen, J. (2006): Soil Erosion in Europe. Wiley, Chichester. 
BOWYER-BOWER, T.A.S. (1993): Effects of rainfall intensity and antecedent moisture on the steadystate infiltration rate in a semi-arid region. Soil Use and Management, 9. 69-76.

CENTERI, C. (2006): Data on particle size distribution under different rainfall intensities on black fallow plots. Conference Proceedings of the 14th International Poster Day. Transport of Water, Chemicals and Energy in the System Soil-Crop CanopyAtmosphere. CD, pp. 106-111.

Cerdan, O., Govers, G., Le Bissonnais, Y., Van Oost, K., Poesen, J., Saby, N., DOSTAL, T. (2010): Rates and spatial variations of soil erosion in Europe: a study based on erosion plot data. Geomorphology. 122. 167-177.

Chen L., Huang Z., Gong J., Fu B., Huang Y. (2007): The effect of land cover/vegetation on soil water dynamic in the hilly area of loess plateau, China. Catena. 70. (2) 200-208.

Comino, J.R., Brings, C., Lassu, T., Iserloh, T., Senciales, J.M., Martínez Murillo, J.F., Ruiz SinogA, J.D., SEeger, M., RIES, J.B. (2015): Rainfall and human activity impacts on soil losses and rill erosion in vineyards (Ruwer Valley, Germany). Solid Earth. 6. 823-837

De Vente, J., Poesen, J. (2005): Predicting soil erosion and sediment yield at the basin scale: scale issues and semi-quantitative models. Earth-Sci. Rev. 71. 95-125.

Erskine Wayne, D., Mahmoudzadeh, A., Myers, C. (2002): Land use effects on sediment yields and soil loss rates in small basins of Triassic sandstone near Sydney, NSW, Australia. Catena. 49. (4) 271-287.

Felix-Henningsen, P., Morgan, R.P.C., Mushala, H.M., Richson, R.J., Scholten, T. (1997): Soil erosion in Swaziland: a synthesis. Soil Technol. 11. 319-329.

Fiener, P., SEIBERT, S., AuERswald, K. (2011): A compilation and meta-analysis of rainfall simulation data on arable soils. Journal of Hydrology. 409. 395-406.

HILL, J., SCHÜTT, B. (2000): The use of remote sensing satellites for mapping complex patterns of erosion and stability in arid Mediterranean ecosystems. RemoteSens. Environ. 74. 557-569.

IPCC (2013): Climate Change 2013: the Physical Science Basis. Contribution of Working Group I to the Fifth Assessment Report of the Intergovernmental Panel on Climate Change. Cambridge University Press, Cambridge, New York.

ISERloh, T., Fister, W., SEeger, M., Willger, H., Ries, J.B. (2012): A small portable rainfall simulator for reproducible experiments on soil erosion. Soil \& Tillage research. 124. 131-137.

JAKAB, G., SzABÓ, J., SzALAI, Z. (2015): Lepeleróziós vizsgálatok eredményei Magyarországon. Tájökológiai Lapok. 13. (1) 89-103.

JAKAB, G., SzALAI, Z. (2005): Barnaföld erózióérzékenységének vizsgálata esőztetéssel a Tetves-patak vízgyüjtőjén. Tájökológiai Lapok. 3. 177-189.

Jones, M.R., Blenkinsop, S., Fowler, H.J., KIlsBy, C.G. (2014): Objective classification of extreme rainfall regions for the UK and updated estimates of trends in regional extreme rainfall. Int. J. Climatol. 34. (3) 751-765.

Jordan, G., Van rompaey, A., Szilassi, P., Csillag, G., Mannaerts, C., Woldai, T. (2005): Historical land use changes and their impact on sediment fluxes in the Balaton basin (Hungary). Agriculture, Ecosystems and Environment. 108. 119-130. 
Kato, H., ONDA, Y., TANAKA, Y., AsANO, M. (2009): Field measurement of infiltration rate using an oscillating nozzle rainfall simulator in the cold, semiarid grassland of Mongolia. Catena. 763. 173-181.

Kertész, Á., MADArÁsz, B., CSEPInSzKY, B., Benke, S. (2010): The role of conservation agriculture in landscape protection. Hungarian Geographical Bulletin, 59. (2) 167-180.

Koler, S.A., Frasier, G.W., TrLiCA, M.J., ReEDER, J.D. (2008): Microchannels affect runoff and sediment yield from a shortgrass prairie. Rangeland Ecology \& Management. 61. 521-528.

Koulouri M., Giourga C. (2007): Land abandonment and slope gradient as key factors of soil erosion in Mediterranean terraced lands. Catena. 69. (3) 274-281.

LAL, R. (1998): Soil erosion impact on agronomic productivity and environment quality. Crit. Rec. Plant Sci. 17. 319-464.

LAL, R. (Ed.) (1999): Soil Quality and Soil Erosion. Soil and Water Conservation Society, Ankeny, IA.

LAL, R. (2003): Soil erosion and the global carbon budget. Environ. Int. 29. (4) 437-450.

Le Bissonnais, Y., Cerdan, O., Lecomte, V., Benkhadra, H., Souche`re, V., MARTIN, P. (2005): Variability of soil surface characteristics influencing runoff and interrill erosion. Catena. 62. 111-124.

Leys, A., Govers, G., GiLliJns, K., Poesen, J. (2007): Conservation tillage on loamy soils, explaining the variability in interrill runoff and erosion reduction. Eur. J. Soil Sci. 58. 1425-1436.

LI, Z., FANG, H. (2016): Impacts of climate change on water erosion: A review. EarthScience Reviews. 163. 94-117.

Mohammad Ayed G., Mohammad A. A. (2010): The impact of vegetative cover type on runoff and soil erosion under different land uses. Catena. 81. (2) 97-103.

Morgan, R.P.C. (2009): Soil Erosion and Conservation. John Wiley \& Sons, 320 pp.

NASSIF, S.H., WILSON, E.M. (1975): The influence of slope and rain intensity on runoff and infiltration. Hydrological Sciences Bulletin. 20. 539-553.

NeAring, M.A., Pruski, F.F., O'NeAL, M.R. (2004): Expected climate change impacts on soil erosion rates: a review. J. Soil Water Conserv. 59. (1) 43-50.

PENGA, T., WANG, S. (2012): Effects of land use, land cover and rainfall regimes on the surface runoff and soil loss on karst slopes in southwest China. Catena. 90. 53-62.

Petö, Á., BuCsi, T., Centeri, C. (2008): Comparison of soil properties on slopes under different land use forms. Proceedings of the 15th International Congress of ISCO, Soil and Water Conservation, "Climate Change and Environmental Sensitivity" on CD, pp. 1-4.

Podmanicky, L., BAlÁZs, K., BelÉnyesi, M., Centeri, C., Kristóf, D., KohlHeb, N. (2011): Modelling soil quality changes in Europe. An impact assessment of land use change on soil quality in Europe. Ecological Indicators. 11. 4-15.

RibolzI, O., PAtin, J., Bresson, L.M., LATSAChaCK, K.O., Mouche, E., Sengtaheuanghoung, O., Silvera, N., ThiéBauX, J.P., Valentin, C. (2011): Impact of slope gradient on soil surface features and infiltration on steep slopes in northern Laos. Geomorphology. 127. (1-2) 53-63.

RIMAL, B.K., LAL, R. (2009): Soil and carbon losses from five different land management areas under simulated rainfall. Soil \& Tillage Research. 106. 62-70. 
Rodriguez, A.R., Guerra, J.A., Gorrin, S.P., Arbelo, C.D., MorA, J.L. (2002): Aggregates stability and water erosion in Andosols of the Canary Islands. Land Degrad. Dev. 13. 515-523.

RoutscheK, A., SCHMIDT, J., KREIENKAMP, F. (2014): Impact of climate change on soil erosion - a high-resolution projection on catchment scale until 2100 in Saxony/Germany. Catena. 121. 99-109.

Quinton, J.N., Govers, G., VAn OOST, K., BARDgetT, R.D. (2010): The impact of agricultural soil erosion on biogeochemical cycling. Nat. Geosci. 3. 311-314.

Schiettecatte, W., Gabriels, D., Cornelis, W.M., Hofman, G. (2008): Enrichment of organic carbon in sediment transport by inter-rill and rill erosion processes. Soil Sci. Soc. Am. J. 72. 50-55.

Sharpley, A.N., Chapra, S.C., WedePOHL, R., Sims, J.T., DANIEl, T.C., RedDy, K.R. (1994): Managing agricultural phosphorus for protection of surface waters: issues and options. J. Environ. Qual. 23. 437-451.

SHEN, H., ZHENG, F., WEN, L., HAN, Y., HU, W. (2016): Impacts of rainfall intensity and slope gradient on rill erosion processes at loessial hillslope. Soil \& Tillage Research. 155. 429-436.

Sheridan, G.J., Noske, P.J., LANE, P.N.J., Sherwin, C.B. (2008): Using rainfall simulation and site measurements to predict annual interrill erodibility and phosphorus generation rates from unsealed forest roads, Validation against in-situ erosion measurements. Catena. 73. 49-62.

Szabó, B., Centeri, C., Szalai, Z., JAKAB, G., SzABÓ, J. (2015): Comparison of soil erosion dynamics under extensive and intensive cultivation based on basic soil parameters. Növénytermelés. 64. 23-26.

Szalai, Z, Szabó, J, Kovács, J, MészÁros, E, Albert, G, Centeri, C, Szabó, B, MADARÁSZ, B, ZACHÁRY, D, JAKAB, G. (2016): Redistribution of soil organic carbon triggered by erosion at field scale under subhumid climate, Hungary. Pedosphere. 26. (5) 652-665.

SzILASSI, P., JORDAN, G., VAN ROMPAEY, A., CsILlAG, G. (2006): Impacts of historical land use changes on erosion and agricultural soil properties in the Kali Basin at Lake Balaton, Hungary. Catena. 68. (3) 96-108.

Vacca, A., Loddo, S., Ollesch, G., Puddu, R., Serra, G., Tomasi, D., Aru, A. (2000): Measurement of runoff and soil erosion in three areas under different land use in Sardinia (Italy). Catena. 40. (1) 69-92.

Verstraeten, G., Poesen, J. (2000): The importance of sediment characteristics and trap efficiency in assessing sediment yield using retention ponds. Phys. Chem. Earth. 26. 83-87.

Won, C.H., CHOI, Y.H., SHIN, M.H., LIM, K.J., CHOI, J.D. (2012): Effects of rice straw mats on runoff and sediment discharge in a laboratory rainfall simulation. Geoderma. 189-190. 164-169. 